\section{Maa, jota ei ole}

Lahtinen, Mikko (toim.) (2017). Tommaso Campanella, Francis Bacon \& David Hume. Matkoja utopiaan. Suom. Pia Mänttäri, Topi Makkonen, Petri Koikkalainen \& Tuukka Tomperi.

Vastapaino. 320 sivua.

TEOS SISÄLTÄÄ kolme klassista utopiakuvausta johdantoineen sekä toimittajan laajan esseen utopiagenrestä. Tommaso Campanellan Aurinkokaupunki ja Francis Baconin Uusi Atlantis sijoittuvat myöhäisrenessanssiin, David Humen Täydellisen valtion idea ajoittuu valistuksen aikakauteen.

Utopiakuvaus voi suuntautua yhtä hyvin menneeseen kuin tulevaan. Vanhin tunnettu lajin edustaja lienee Hesiodoksen Työt ja päivät (700-luvulla eaa.), joka kuvaa ihmissuvun vaiheittaista taantumista kulta-ajasta rauta-aikaan. Kertomuksessa voidaan kirjan toimittaneen Mikko Lahtisen loppusanojen mukaan nähdä samankaltaisuutta muinaisten itäisten myyttien kanssa.

Filosofian historian ensimmäinen merkittävä utopiateos on Platonin (384-322 eaa.) Valtio. Roomalainen Cicero (106-43 eaa.) sovelsi omaan aikaansa oppeja valtiosta ja kansalaishyveistä. Hänen aristokraattiseen ihmisihanteeseensa kuuluivat niin vita activa kuin vita comtemplativa. Raamatun kautta ovat tulleet länsimaihin käsitykset menneisyyden syntiinlankeemuksesta sekä pikaisesta ja väistämättömästä maailmanlopusta tulevaisuudessa.

\section{ON USKALLETTAVA KYSYÄ}

U-topos tarkoittaa jotain, jota ei ole missään. Sanan merkitys voi olla myös onnellisten paikka. Utopiatermin otti samannimisessä teoksessaan käyttöön lontoolainen Thomas More (1478-1535). Hän ei tukenut riittävästi Henrik VIII:n pyrkimystä nousta Englannin kirkon pääksi ja samalla vaihtaa puolisonsa nuorempaan ja menetti siitä hyvästä päänsä.

Runsas utopiakirjallisuuden lajityyppi on vuosisatojen mittaan saanut vaihtelevasti arvostusta. Valistusajan Ranskassa utopismin lähes synonyymiksi tuli Kreikan mytologiaolento khimaira, jonka etuosa on leijona, keskiosa vuohi ja takaosa käärme.

Utopioita kuitenkin tarvitaan muistuttamaan, että asiat voivat olla myös toisin. Saksalaissyntyinen sosiologi Karl Mannheim (1893-1947) viittaa utopialla oppiin tai teoriaan, joka on vielä haastajan asemassa. Vallitsevaksi tullessaan oppi muuttuu itsestäänselvyydeksi ja ideologiaksi. Kaiken utooppisen hylkääminen johtaisi 'tosiasiamaisuuteen' (matter-offactness) ja inhimillisen tahdon rappeutumiseen, siteeraa Lahtinen Mannheimia. André Gorzin (1923-2007) mukaan vallanpitäjät asettavat vain kysymyksiä, joita he pystyvät ratkaisemaan, mutta

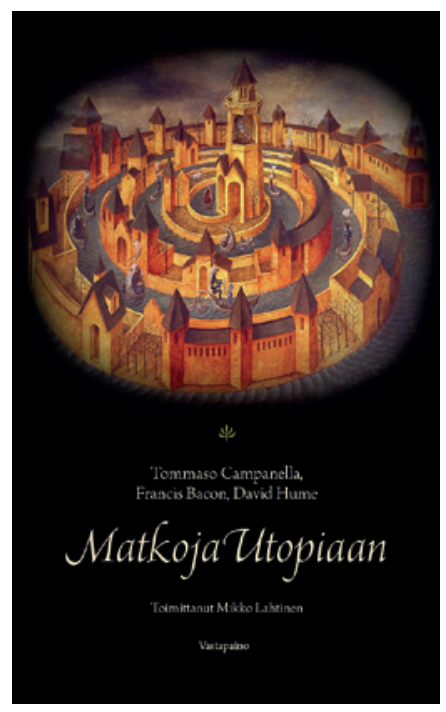

on uskallettava kysyä myös sellaista, mihin kysyjällä ei ole vastausta.

\section{TÄYDELLINEN, SYMMETRINEN} KAUPUNKI

Kirjaan sisältyvä Tommaso Campanellan (1568-1639) Aurinkokaupunki (1602) tuntuu oudon tutulta. Italo Calvinon teoksessa Näkymättömät kaupungit (1976) Kublai-kaani kyselee Marco Pololta laajan valtakuntansa merkillisistä, symmetrisistä kaupungeista. Campanellan teoksessa Johanniitta kyselee symmetrisestä kaupungista Kolumbuksen perämieheltä Genovalaiselta.

Aurinkokaupungin henkisen ja maallisen elämän pää on pappisruhtinas Aurinko, "jota meidän kielellämme voisi kutsua Metafyysikoksi” (s. 32). Hänen alapuolellaan ovat ruhtinaat Valta, Viisaus ja Rakkaus. Kutakin hyvettä johtavat viranomaiset. 
Tehtävään valitaan ne, joilla on asian harrastusta jo kouluiässä.

Viisaus-ruhtinaan alaisina ovat kunkin tieteen päälliköt. Kaikki tieteet on kirjattu yhteen kirjaan, jota kansa saa lukea. Lisäksi tieteet ja tieto on kuvattu muureihin, mistä lapset ne oppivat "vaivatta, leikin varjolla" ennen kymmenettä ikävuottaan. Vanhukset vievät lapsia eri alojen verstaisiin selvittelemään taipumuksiaan. Tieteiden ja käytännön taitojen opiskelu on yhtä arvokasta.

UUSI ATLANTIS JA TÄYDELLINEN VALTIO

Paroni ja varakreivi Francis Bacon (1561-1626) oli itse keksi- mänsä termin mukaan rojalisti ja sai parlamentarismin kannattajilta syytteen lahjusten otosta. Lordikanslerin asemasta pudottuaan hän teki toisen uran filosofina ja ensimmäisenä englanninkielisenä esseistinä.

Baconin Uusi Atlantis (1627) kuvaa monarkiaa. Saarella vallitsee perhekeskeisyys, patriarkaatti, asiantuntija- ja virkamiesvaltaisuus, jo ennen Raamatun julkaisemista (sic) omaksuttu kristillisyys sekä kokeellisen ja induktiivisen menetelmän avulla edistyvä tiede. Tiedettä ei kontrolloi valtio, vaan tiedeyhteisöllä on autonominen asema. "Maailman kaikista kolkista me etsimme tiedon kirkasta valoa" (s. 129), kertoo valtion johtohenkilö saareen ajautuneille merimiehille.

Kirjan kolmas utopia, skottilaisen tyylitaiturin David Humen (1711-76) Täydellisen valtion idea (1752) on pikemminkin valtioopin oppikirja kuin varsinainen utopia. Humen rauhattomuutta herättävä ajatus oli, että kaikki ihmisen tekemä, kuten hallintojärjestelmä, voisi olla myös toisin.

Huolellisesti toimitettua ja hyvän kokonaisuuden tarjoavaa teosta voi suositella utopioista ja historiasta kiinnostuneille.

\section{JUSSI ONNISMAA}

FT, dosentti, tietokirjailija

Werka kehitys Oy 